\title{
B-Radiation Stress Responses on Growth and Antioxidative Defense System in Plants: A Study with Strontium-90 in Lemna minor
}

\section{Arne Van Hoeck ${ }^{1,2, *}$, Nele Horemans ${ }^{1,3}$, May Van Hees ${ }^{1}$, Robin Nauts ${ }^{1}$, Dries Knapen ${ }^{4}$, Hildegarde Vandenhove ${ }^{1}$ and Ronny Blust ${ }^{2}$}

1 SCK•CEN, Belgian Nuclear Research Centre, Boeretang 200, 2400 Mol, Belgium; E-Mails: nhoreman@sckcen.be (N.H.); mvhees@sckcen.be (M.V.H.); rnauts@sckcen.be (R.N.); hvandenh@sckcen.be (H.V.)

2 Department of Biology, University of Antwerp, Groenenborgerlaan 171, 2020 Antwerpen, Belgium; E-Mail: ronny.blust@uantwerpen.be

3 Centre for Environmental Research, University of Hasselt, Universiteitslaan 1, 3590 Diepenbeek, Belgium

4 Veterinary Sciences, University of Antwerp, Groenenborgerlaan 171, 2020 Antwerpen, Belgium; E-Mail: dries.knapen@uantwerpen.be

* Author to whom correspondence should be addressed; E-Mail: avhoeck@sckcen.be; Tel.: +32-14-33-23-82.

Academic Editor: Ann Cuypers

Received: 28 May 2015 / Accepted: 26 June 2015 / Published: 7 July 2015

\begin{abstract}
In the following study, dose dependent effects on growth and oxidative stress induced by $\beta$-radiation were examined to gain better insights in the mode of action of $\beta$-radiation induced stress in plant species. Radiostrontium $\left({ }^{90} \mathrm{Sr}\right)$ was used to test for $\beta$-radiation induced responses in the freshwater macrophyte Lemna minor. The accumulation pattern of ${ }^{90} \mathrm{Sr}$ was examined for L. minor root and fronds separately over a seven-day time period and was subsequently used in a dynamic dosimetric model to calculate $\beta$-radiation dose rates. Exposing L. minor plants for seven days to a ${ }^{90} \mathrm{Sr}$ activity concentration of 25 up to $25,000 \mathrm{kBq} \cdot \mathrm{L}^{-1}$ resulted in a dose rate between $0.084 \pm 0.004$ and $97 \pm 8 \mathrm{mGy} \cdot \mathrm{h}^{-1}$. After seven days of exposure, root fresh weight showed a dose dependent decrease starting from a dose rate of $9.4 \pm 0.5 \mathrm{mGy} \cdot \mathrm{h}^{-1}$. Based on these data, an $\mathrm{EDR}_{10}$ value of $1.5 \pm 0.4 \mathrm{mGy} \cdot \mathrm{h}^{-1}$ was estimated for root fresh weight and $52 \pm 17 \mathrm{mGy} \cdot \mathrm{h}^{-1}$
\end{abstract}


for frond fresh weight. Different antioxidative enzymes and metabolites were further examined to analyze if $\beta$-radiation induces oxidative stress in L. minor.

Keywords: radiation responses; abiotic stress; dosimetry; Lemna minor; oxidative stress; strontium-90

\section{Introduction}

Anthropogenic activities have led to enhanced releases of fission products from nuclear facilities into the environment. Many of these fission products are radionuclides that are short-lived $\gamma$ - and $\beta$-emitting isotopes, which rapidly lose their radioactivity. However, some radionuclides have a physical half-life that takes several years and therefore can contribute to a long-lasting contamination of the biosphere [1]. Among the artificially produced radionuclides, strontium-90 $\left({ }^{90} \mathrm{Sr}\right)$ is of particular interest due to its relative long physical half-live of 28.6 years. It is produced with high yields as a byproduct of the fission of uranium and plutonium and is thus a common waste product from nuclear activities [2]. Also, the explosions of nuclear weapons in the 1950s and 1960s contributed to the widespread distribution of ${ }^{90} \mathrm{Sr}$ in the environment [3]. More recently, ${ }^{90} \mathrm{Sr}$ was accidently released during nuclear meltdown in Fukushima in 2011 [4] and in substantial amounts in Chernobyl in 1986 [5]. Geochemical studies revealed that large amount of this radionuclide can be transported via rivers to the ocean or could accumulate in freshwater reservoirs where it can remain for many years $[4,6]$. As ${ }^{90} \mathrm{Sr}$ decays, it releases moderate energy $\beta$-particles and forms yttrium-90, which in turn emits very strong energetic $\beta$-particles within $64 \mathrm{~h}$ to stable zirconium. Since most of the energy from such $\beta$-particles is absorbed by surface tissues, the bioaccumulation of these radionuclides can potentially produce deleterious effects to the health of living organisms [1].

Radioecological research on $\beta$-emitting isotopes in plants has mainly focused on ${ }^{90} \mathrm{Sr}$ accumulation in edible plants, in particular crops [7-10] or on exploring the use of plants in phytoremediation strategies i.e., to decontaminate soils contaminated with low levels of ${ }^{90} \mathrm{Sr}$ [11-14]. A number of studies report on a reduction in plant growth at elevated $\mathrm{Sr}$ concentrations [10,15-17]. However, these focused on stable $\mathrm{Sr}$ at the mM-level. Biological responses induced by $\beta$-radiation from ${ }^{90} \mathrm{Sr}$ have, to date, not been studied in detail in plants [18]. Only one study examined the photosynthetic response induced by high ${ }^{90} \mathrm{Sr}$ exposure levels [19]. Relative biological effectiveness (RBE) values can be used to extrapolate the biological responses for different types of radiation in non-human biota. Since RBE values for high-energy $\beta$-radiation are equal to $\gamma$-radiation, similar radiation responses can be expected compared to $\gamma$-radiation exposure [20]. A transcriptomic study revealed similar stress responses, defense responses and metabolic processes of rice seedlings exposed differentially to either $\gamma$-radiation or particle radiation [21]. High levels of ionizing radiation often lead to an increase in the formation of highly reactive oxygen species (ROS), which may cause oxidative stress, a disturbance of the cellular redox status, as is observed after exposure to other environmental stressors [22,23]. These ROS molecules are also generated as byproducts of normal oxidative metabolism and play an imported role in signaling and oxidative stress responses. Under abiotic stress, an imbalance between oxidative and reductive processes in the cell is generated. Plants have antioxidative defense systems to counteract the 
elevated ROS levels. These comprise of low molecular weight antioxidants like reduced glutathione (GSH) and ascorbate (ASC). The metabolites are key players in the ASC-GSH cycle, forming an important mechanism of the antioxidative defense system [24]. Other antioxidative biomolecules include antioxidative enzymes such as catalase (CAT), glutathione reductase (GR), superoxide dismutase (SOD), ascorbate peroxidase (APOD), syringaldizyne peroxidase (SPOD) and guaiacol peroxidase (GPOD). Together these enzymatic and non-enzymatic antioxidants can scavenge different free radical elements in order to maintain the redox balance in the cell and to protect biomolecules from oxidative attacks. Different studies already highlighted the importance of such antioxidative enzymes and metabolites to handle $\gamma$-radiation exposure treatment in plants $[25,26]$. However, antioxidative defense mechanisms have never been examined in $\beta$-irradiated plants.

Although $\mathrm{Sr}$ is not essential for plant metabolism, it bears a chemical analogy with the essential plant macronutrient $\mathrm{Ca}$. In terrestrial plants, the uptake of $\mathrm{Ca}$ occurs mainly via $\mathrm{Ca}$ channels in the roots [27]. Calcium ATPases are also present in the roots and catalyze the Ca influx and efflux across the plasma membrane of endodermal cells. Calcium is then transported to the shoots via the xylem where the excess of $\mathrm{Ca}$ is stored in vacuoles to keep the Ca concentration in cytosol at a basal level. Kinetic studies of $\mathrm{Ca}$ in combination with $\mathrm{Sr}$ pointed out that both compounds have almost identical uptake efficiencies $[11,17,28]$. Furthermore, it has been found that once taken up, like $\mathrm{Ca}, \mathrm{Sr}$ is exclusively transported via the xylem, which further led to the conclusion that plants do not discriminate $\mathrm{Sr}$ and $\mathrm{Ca}$ ions [29,30]. Calcium oxalate crystals are formed at toxic $\mathrm{Ca}$ concentration in plants and when $\mathrm{Sr}$ is added to nutrient solutions, it has been found that $\mathrm{Sr}$ is incorporated in $\mathrm{Ca}$ oxalate crystals in L. minor [31,32]. Overall, plants seem to have the capacity to accumulate Sr-ions, thereby taking advantage of $\mathrm{Ca}$ uptake and transport mechanisms. Therefore, it is conceivable that when the radioactive isotope ${ }^{90} \mathrm{Sr}$ accumulates, it can subsequently deliver a considerable $\beta$-radiation dose to the plant organs.

Lemna minor was selected as a biological model to study irradiation effects following $\beta$-radiation exposure. This free-floating vascular macrophyte develops roots and has the potential to take up nutrients through both fronds and roots. L. minor is to date the only freshwater plant model for testing metal biomonitoring and other toxic chemicals in freshwater ecosystems [33,34]. This bio-test includes a seven-day experiment to evaluate growth related endpoints. This study reports on the responses of L. minor to $\beta$-radiation by using ${ }^{90} \mathrm{Sr}$ as $\beta$-emitting isotope. First, the uptake pattern of ${ }^{90} \mathrm{Sr}$ was characterized over a seven-day time period to construct a dynamic dosimetric model to determine internal and external exposures rates. Afterwards, L. minor plants were exposed to different ${ }^{90} \mathrm{Sr}$ concentrations in order to study possible dose dependent relationships. The classical growth related endpoints were evaluated and compared with antioxidative defense system endpoints. Our findings contribute to a better insight into the antioxidant defense system in plants following $\beta$-radiation.

\section{Results}

\section{1. ${ }^{90} \mathrm{Sr}$ Uptake and Dosimetry}

L. minor plants were continuously exposed for seven days to four different activity concentrations from 25 up to $25,000 \mathrm{kBq} \cdot \mathrm{L}^{-1}$ to study dose dependent relationships of $\beta$-radiation. In order to 
constitute a maximal ${ }^{90} \mathrm{Sr}$ uptake and accumulation, L. minor plants were exposed in a medium containing $0.2 \mathrm{mM} \mathrm{Ca}$. The ${ }^{90} \mathrm{Sr}$ concentration ratios (CR) to frond and root expressed on fresh and dry weigh basis are shown in Table 1. Although the CRDw of the highest tested activity concentration was slightly lower compared with other tested activity concentrations, no significant differences in CRDW were observed between tested $\mathrm{Sr}$ activity concentrations from non-exposed plants (ANOVA, $p<0.05$ ). It was found that the ${ }^{90} \mathrm{Sr}$ content was similar in both plant organs (fronds and roots) indicated by equivalent $\mathrm{CR}_{\mathrm{DW}}$ for each tested activity concentration. In contrast, the CRs expressed on plant fresh weight (CRFw) and used in dosimetry calculations, were remarkably lower in the roots compared to the fronds. The $\mathrm{CR}_{\mathrm{FW}}$ in this study were approximately 60 and $30 \mathrm{~Bq} \cdot \mathrm{kg}^{-1} \mathrm{FW} / \mathrm{Bq} \cdot \mathrm{L}^{-1}$ for fronds and roots respectively. As for $\mathrm{CR}_{\mathrm{DW}}$, no concentration-dependent differences in CRs were observed for the tested activity concentrations. ${ }^{90} \mathrm{Sr}$ uptake in L. minor roots and fronds was monitored over a seven-day period in order to enable more correct dose assessment estimations. With the tested ${ }^{90} \mathrm{Sr}$ activity concentration used in this experiment, the activity of ${ }^{90} \mathrm{Sr}$ found in roots increased rapidly during the first $8 \mathrm{~h}$, then much slower during the next $72 \mathrm{~h}$ before it tended to stabilize (Figure 1). About $92 \% \pm 3 \%$ of the ${ }^{90} \mathrm{Sr}$ uptake capacity at equilibrium phase (at which the net uptake is zero) of the L. minor fronds and $97 \% \pm 4 \%$ of the roots was accumulated after $72 \mathrm{~h}$ of exposure. These time-dependent uptake parameters and the respective $\mathrm{CR}_{\mathrm{FW}}$ were considered to calculate accurate dose rates for L. minor organs (fronds and roots) exposed over a seven-day exposure. Calculating internal and external dose rates for roots and fronds separately, the exposure of $L$. minor plants to ${ }^{90} \mathrm{Sr}$ activity concentration from 25 up to $25,000 \mathrm{kBq} \cdot \mathrm{L}^{-1}$ resulted in a total dose rate ranging from $0.084 \pm 0.004$ and $97 \pm 8 \mathrm{mGy} \cdot \mathrm{h}^{-1}$ for the L. minor plants (Table 1). The estimated absorbed dose rates from internal exposure were generally one order of magnitude higher than those from external exposure.

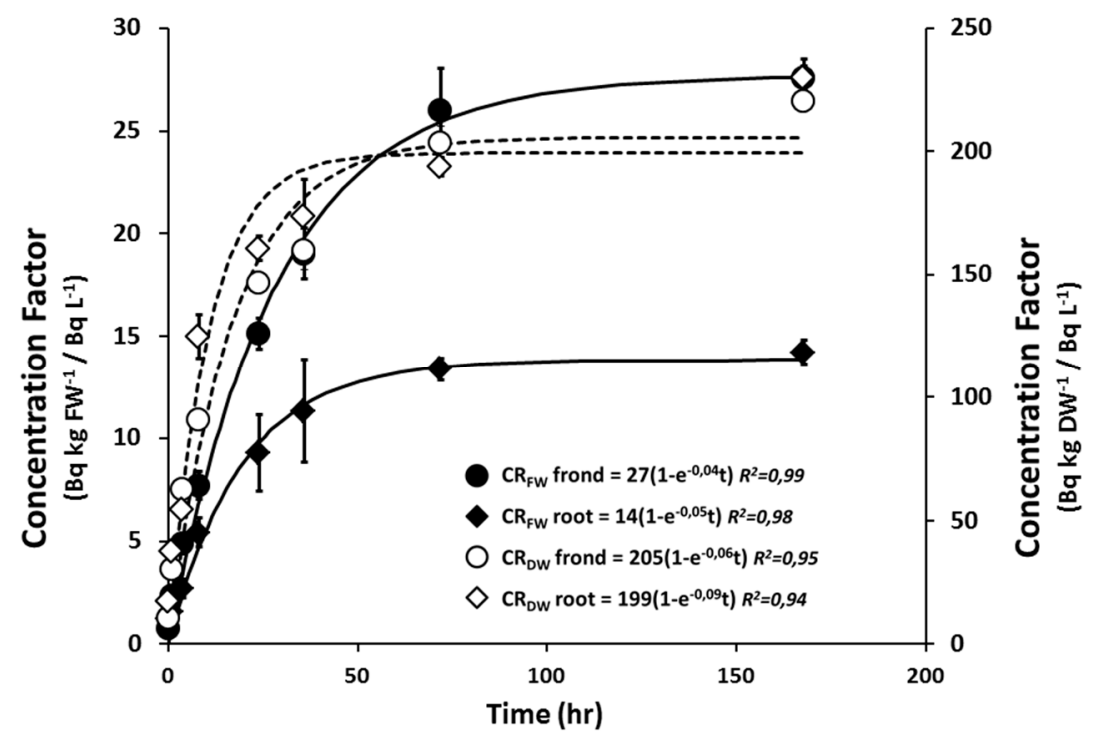

Figure 1. Time course of $\mathrm{Sr}^{90}$ uptake in L. minor for time period of 168 hours exposed to $10 \mathrm{kBq} \cdot \mathrm{L}^{-1}$ of ${ }^{90} \mathrm{Sr}$. Black dots refers to concentration ratios on fresh weight for frond and root, white dots refers to concentration ratios on dry weight for frond and root. Legend shows the equation of each fit with the $R^{2}$ value. Each data point represents the mean $\pm \mathrm{SE}$ of six biological replicas. 
Table 1. Nominal and measured medium activity concentrations of ${ }^{90} \mathrm{Sr}$, biomass of $L$. minor fronds and roots given as fresh weight (FW) and dry weight (DW) of each activity concentration, ${ }^{90} \mathrm{Sr}$ concentration ratios expressed in fresh weights and dry weights for $L$. minor fronds and roots after seven days of exposure and the calculated absorbed dose rates in L. minor organs. All values are given as mean \pm SE with at least three biological replicates. Significant differences from control plants ( $p<0.05$, one-way ANOVA) are given as *.

\begin{tabular}{|c|c|c|c|c|c|c|c|c|c|}
\hline \multicolumn{2}{|c|}{ Activity Concentration } & & \multicolumn{2}{|c|}{ Biomass } & \multicolumn{2}{|c|}{ Uptake Parameters } & \multicolumn{3}{|c|}{ Dosimetric Parameters } \\
\hline $\begin{array}{l}\text { Nominal } \\
{\left[\mathbf{k B q} \cdot \mathbf{L}^{-1}\right]}\end{array}$ & $\begin{array}{l}\text { Measured } \\
{\left[\mathrm{kBq} \cdot \mathbf{L}^{-1}\right]}\end{array}$ & & $\begin{array}{l}\text { FW } \\
{[\mathrm{mg}]}\end{array}$ & $\begin{array}{l}\text { DW } \\
{[\mathrm{mg}]}\end{array}$ & $\begin{array}{c}\text { Conc. Ratio FW } \\
\begin{array}{c}{\left[\mathbf{B q} \cdot \mathbf{k g}^{-1} \mathbf{F W} /\right.} \\
\left.\mathbf{B q} \cdot \mathbf{L}^{-1}\right]\end{array}\end{array}$ & $\begin{array}{c}\text { Conc. Ratio DW } \\
\begin{array}{c}{\left[\mathrm{Bq} \cdot \mathbf{k g}^{-1} \mathbf{D W} /\right.} \\
\left.\mathbf{B q} \cdot \mathbf{L}^{-1}\right]\end{array}\end{array}$ & $\begin{array}{c}\text { Dose Rate Intern } \\
\qquad\left[\boldsymbol{\mu G y} \cdot \mathbf{h}^{-1}\right]\end{array}$ & $\begin{array}{c}\text { Dose Rate Extern } \\
\qquad\left[\boldsymbol{\mu G y} \cdot \mathbf{h}^{-1}\right]\end{array}$ & $\begin{array}{c}\text { Total Dose Rate } \\
\qquad\left[\boldsymbol{\mu G y} \cdot \mathbf{h}^{-1}\right]\end{array}$ \\
\hline \multirow[t]{3}{*}{0} & $0 \pm 0.001$ & plant & $199.5 \pm 10$ & $13.9 \pm 0.7$ & na & na & na & na & na \\
\hline & & frond & $165.6 \pm 7.8$ & $12.3 \pm 0.6$ & na & na & na & na & na \\
\hline & & root & $33.8 \pm 2.3$ & $1.6 \pm 0.1$ & na & na & na & na & na \\
\hline \multirow[t]{3}{*}{25} & $25 \pm 0.1$ & plant & $225.3 \pm 10.4$ & $15.3 \pm 0.5$ & $60 \pm 3$ & $832 \pm 21$ & $85 \pm 4$ & $5 \pm 0.2$ & $84 \pm 4$ \\
\hline & & frond & $186 \pm 8.8$ & $13.5 \pm 0.3$ & $62 \pm 2$ & $829 \pm 30$ & $86 \pm 4$ & $5 \pm 0.2$ & $89 \pm 4$ \\
\hline & & root & $38.8 \pm 1.8$ & $1.8 \pm 0.2$ & $28 \pm 2$ & $783 \pm 23$ & $41 \pm 3$ & $10 \pm 0.4$ & $51 \pm 2$ \\
\hline \multirow[t]{3}{*}{250} & $247 \pm 0.1$ & plant & $210.2 \pm 9.6$ & $15.1 \pm 0.9$ & $60 \pm 4$ & $767 \pm 65$ & $918 \pm 63$ & $53 \pm 3$ & $967 \pm 58$ \\
\hline & & frond & $178 \pm 8$ & $13.7 \pm 0.7$ & $65 \pm 5$ & $789 \pm 71$ & $1000 \pm 76$ & $53 \pm 3$ & $1053 \pm 74$ \\
\hline & & root & $31.2 \pm 1.6$ & $1.5 \pm 0.1$ & $29 \pm 1$ & $752 \pm 15$ & $454 \pm 20$ & $107 \pm 5$ & $562 \pm 21$ \\
\hline \multirow[t]{3}{*}{2500} & $2453 \pm 2$ & plant & $195.6 \pm 5.6$ & $14.0 \pm 0.2$ & $60 \pm 3$ & $844 \pm 23$ & $8881 \pm 486$ & $530 \pm 3$ & $9432 \pm 483$ \\
\hline & & frond & $178.5 \pm 5$ & $13.2 \pm 0.3$ & $63 \pm 3$ & $858 \pm 24$ & $9185 \pm 477$ & $530 \pm 3$ & $9715 \pm 476$ \\
\hline & & root & $16.8 \pm 0.7 *$ & $0.9 \pm 0.1 *$ & $37 \pm 3$ & $820 \pm 48$ & $5486 \pm 469$ & $1070 \pm 6$ & $6556 \pm 464$ \\
\hline \multirow[t]{3}{*}{25,000} & $24,567 \pm 13$ & plant & $124.4 \pm 3.4$ & $12.5 \pm 0.1$ & $57 \pm 5$ & $540 \pm 35 *$ & $91,063 \pm 8607$ & $6006 \pm 98$ & $97,264 \pm 8490$ \\
\hline & & frond & $118.7 \pm 3.5 *$ & $12.2 \pm 0.1$ & $59 \pm 6$ & $542 \pm 36 *$ & $92,827 \pm 9130$ & $6006 \pm 98$ & $98,834 \pm 9033$ \\
\hline & & root & $5.7 \pm 0.2 *$ & $0.4 \pm 0.02 *$ & $36 \pm 2$ & $474 \pm 20 *$ & $56,904 \pm 2287$ & $12,121 \pm 197$ & $69,025 \pm 2181$ \\
\hline
\end{tabular}




\section{2. ${ }^{90} \mathrm{Sr}$ Induced Effects in L. minor}

Frond number, frond area and frond and root fresh and dry weight were measured for L. minor plants exposed from $0.084 \pm 0.004 \mathrm{mGy} \cdot \mathrm{h}^{-1}$ up to $97 \pm 8 \mathrm{mGy} \cdot \mathrm{h}^{-1}$. After seven days, frond related growth rates determined based on fresh weight, frond area and number decreased significantly at the highest tested dose rate of $97 \pm 8 \mathrm{mGy} \cdot \mathrm{h}^{-1}$ with an inhibition of $16 \% \pm 3 \%, 18 \% \pm 1 \%$ and $16 \% \pm 3 \%$, respectively (ANOVA, $p<0.05$ ). The growth endpoints measured on root fresh and dry weight were significantly affected at $9.4 \pm 0.5 \mathrm{mGy} \cdot \mathrm{h}^{-1}$. At the highest tested dose rate, root fresh and dry weight was inhibited for $63 \% \pm 1.5 \%$ and $57 \% \pm 0.4 \%$, respectively (Figure 2). The derived EDR 10 -value (Effective Dose Rate) for frond area was $95 \pm 7$, and $154 \pm 15$ and $152 \pm 13 \mathrm{mGy} \cdot \mathrm{h}^{-1}$ for fresh weight and frond number, respectively. The EDR 10 -values for root biomass were $1.5 \pm 0.4$ and $1.0 \pm 0.5 \mathrm{mGy} \cdot \mathrm{h}^{-1}$ for root fresh and dry weight, respectively. Growing L. minor plants in stable Sr concentrations up to $60 \mathrm{nM}$, the equivalent nominal concentration at ${ }^{90} \mathrm{Sr}$ activity concentration of $25,000 \mathrm{kBq} \cdot \mathrm{L}^{-1}$, did not result in a significant difference in growth rate (data not shown). As such, observed growth effects are expected to be linked to ${ }^{90} \mathrm{Sr}$ induced radiotoxicity and not $\mathrm{Sr}$ chemotoxicity.

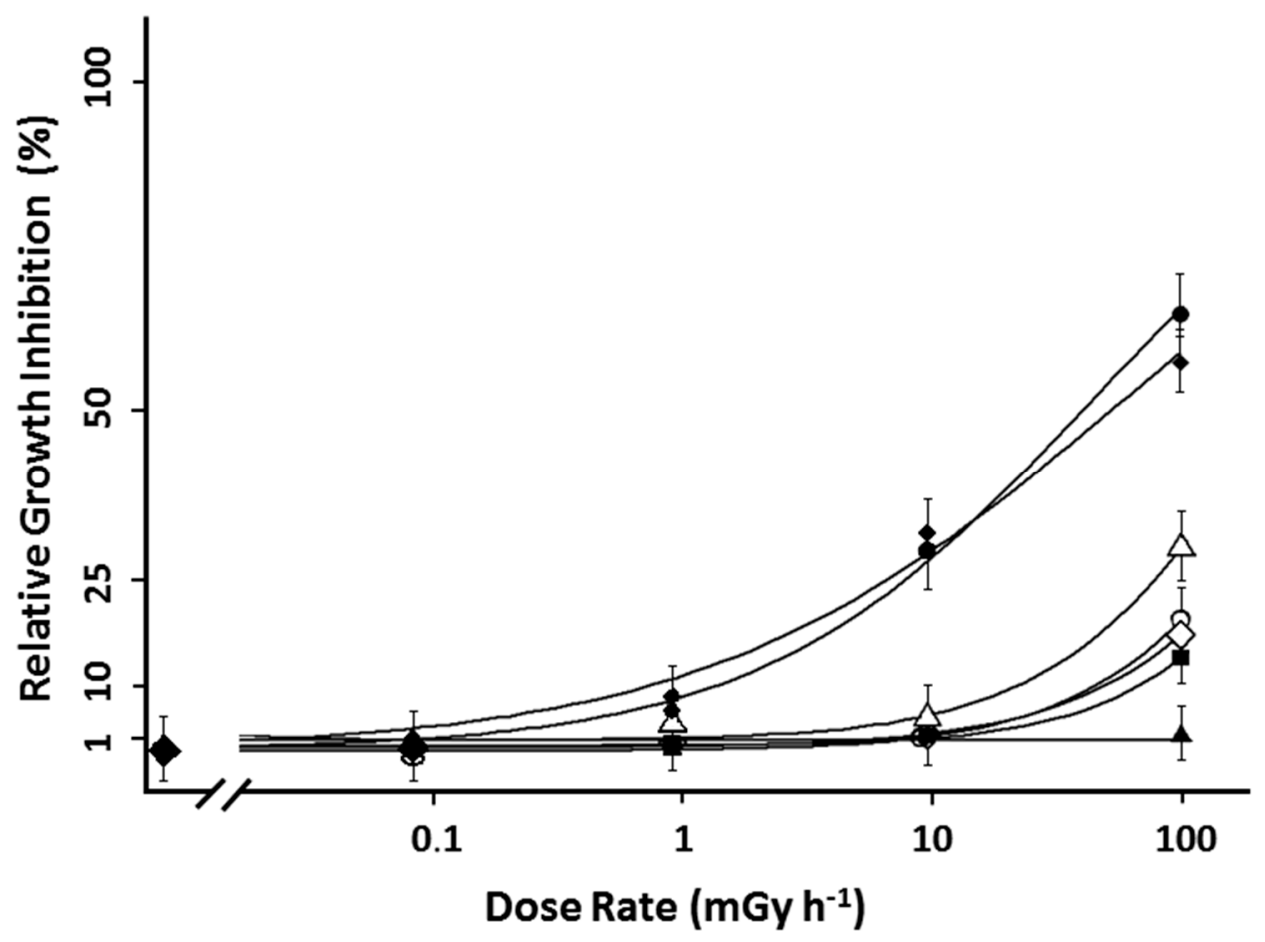

Figure 2. Dose response curve of $L$. minor plants treated for seven days with $\beta$-radation. The dose response curces are given by relative growth inhibition based on frond area $\left(-\triangle^{-}\right)$, frond number $(-\circ)$, plant fresh weight $(-\neg)$, frond fresh weight $(-\bullet)$, frond dry weight $(\neg)$, root fresh weight $(\neg-)$ and root dry weight $(\multimap)$. Each data point represents the mean $\pm \mathrm{SE}$ of nine biological replicas for frond related endpoints and three biological replicas for root related endpoints. In addition to the average values of each point, the log-logistic function fitted through the data is added.

To evaluate oxidative stress induced in $\beta$-exposed $L$. minor plants, antioxidative enzyme activities including CAT, GR, SOD, APX, GPOD and SPOD were analyzed (Figure 3). No significant differences 
in enzyme activities were found in plants exposed to the lowest dose rate at $0.084 \pm 0.004 \mathrm{mGy} \cdot \mathrm{h}^{-1}$. At the next tested dose rate $0.97 \pm 0.06 \mathrm{mGy} \cdot \mathrm{h}^{-1}$, enzyme activities of CAT and APX were significantly enhanced, which remained status quo at the next tested dose rate. At the highest dose rate tested, a significant increase in CAT, APX, GPOD and SPOD activities in comparison to non-treated plants was observed. At the dose rate of $97 \pm 8 \mathrm{mGy} \cdot \mathrm{h}^{-1}$, an approximately twofold increase in activity was evidenced for CAT, while enhancement in activity was less pronounced for the other enzymes. GR and SOD were the only enzymes exhibiting no alterations in activity with increasing dose rate.

Concentrations of oxidized and reduced forms of ASC and GSH were determined to study their redox status (Figure 4). No significant shift in redox status was observed at any dose rate intensity for ASC. In contrast, an increase in GSH content was observed at the highest tested dose rate of $97 \pm 8 \mathrm{mGy} \cdot \mathrm{h}^{-1}$. At this dose rate, the total GSH concentration attained a level of $121 \pm 1 \mathrm{nmol} \cdot \mathrm{g}^{-1} \mathrm{FW}$ while control plants exhibited a GSH concentration of $96 \pm 8 \mathrm{nmol} \cdot \mathrm{g}^{-1} \mathrm{FW}$.
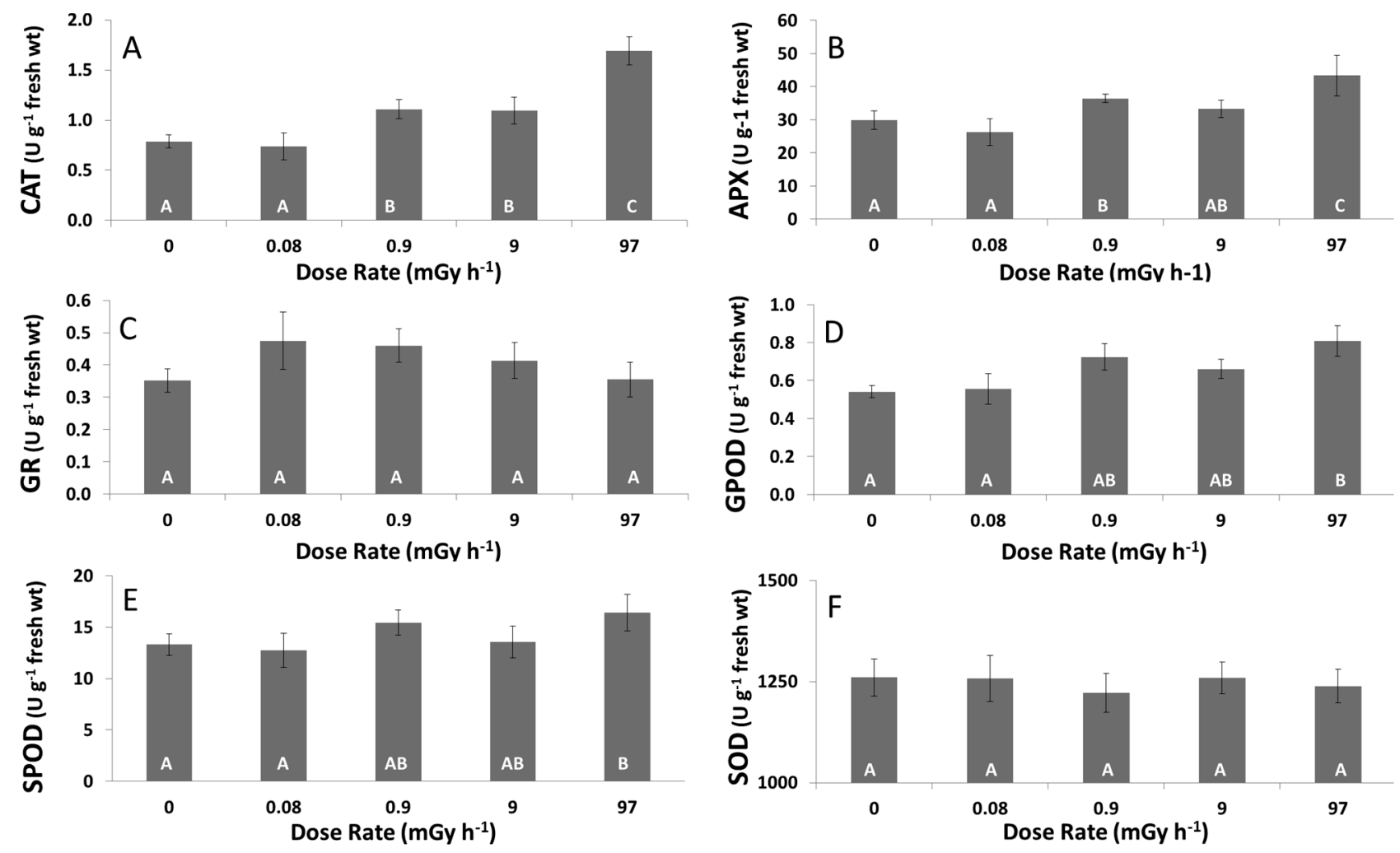

Figure 3. Enzyme activities of (A) catalase (CAT); (B) ascorbate peroxidase (APX); (C) glutathione reductase (GR); (D) guaiacol type peroxidase (GPOD); (E) syringaldizine peroxidase (SPOD); and (F) superoxide dismutase (SOD) in L. minor exposed to different dose rates levels of $\beta$-radation for seven days. Each data point represents the mean $\pm \mathrm{SE}$ of three biological replicas. Different capital letters indicate significant differences between treated plants and control plants ( $p<0.05$, one-way ANOVA). 


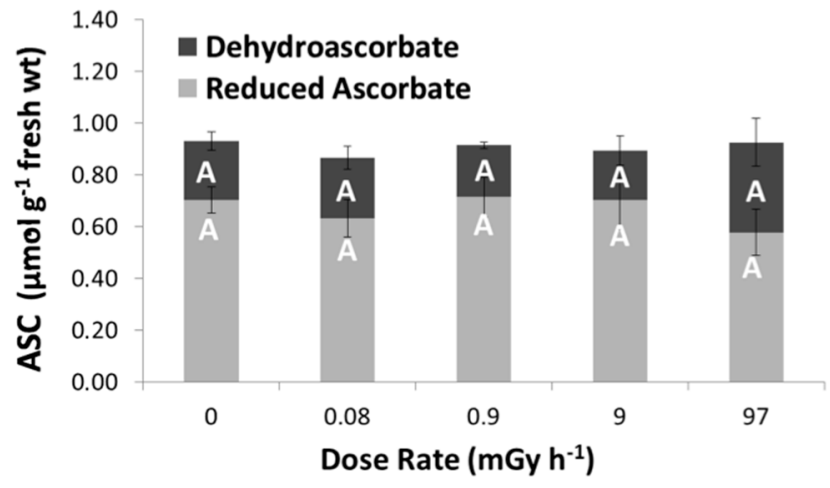

(a)

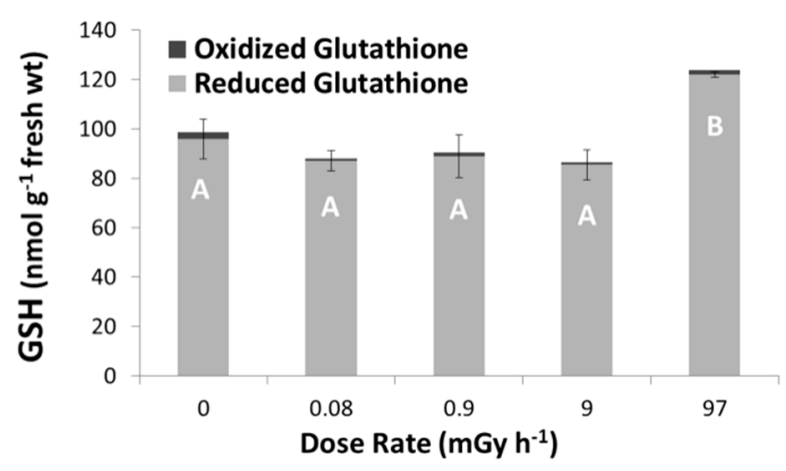

(b)

Figure 4. Metabolite concentrations of (a) ascorbate (ASC) and (b) glutathione (GSH) in L. minor exposed to different dose rates levels of $\beta$-radation for seven days. Concentration levels of reduced and oxidized forms of the metabolites are shown in light and dark grey bars, respectively. Each data point represents the mean \pm SE of three biological replicas. Different capital letters indicate significant differences between treated plants and control plants ( $p<0.05$, one-way ANOVA).

\section{Discussion}

\section{1. ${ }^{90} \mathrm{Sr}$ Accumulation and Uptake}

The present study aimed at evaluating $\beta$-radiation induced growth and oxidative stress responses in L. minor to a range of ${ }^{90} \mathrm{Sr}$ exposure concentrations. Therefore, L. minor plants were exposed above the threshold level of $400 \mu \mathrm{Gy} \cdot \mathrm{h}^{-1}$ since dose rates under this level are considered not to induce detrimental effects to some individuals in aquatic organisms [35]. Exposure media were adjusted with low $\mathrm{Ca}$ concentrations to induce high ${ }^{90} \mathrm{Sr}$ uptake in L. minor plants and subsequent high internal $\beta$-radiation exposure. The time course of ${ }^{90} \mathrm{Sr}$ uptake showed that the ${ }^{90} \mathrm{Sr}$ content of $L$. minor roots and fronds tended to saturate over time. The ${ }^{90} \mathrm{Sr}$ uptake reached a plateau after three days in both roots and shoots, indicating that ${ }^{90} \mathrm{Sr}$ concentration in plants was in equilibrium with the ${ }^{90} \mathrm{Sr}$ concentration of the growth medium. Similar results were obtained with $\mathrm{Sr}$ uptake in large-flowered waterweed and in hydroponically grown maize and sunflower where a steady state for ${ }^{90} \mathrm{Sr} / \mathrm{Sr}$ uptake between was obtained after three to five days [17,36,37]. The $\mathrm{CR}_{\mathrm{FW}}$ in present study were approximately 60 and $30 \mathrm{~Bq} \cdot \mathrm{kg}^{-1} \mathrm{FW} / \mathrm{Bq} \cdot \mathrm{L}^{-1}$ for fronds and roots, respectively. These are among the lower $\mathrm{CR}_{\mathrm{FW}}$ compared to other floating-leafed macrophophytes [38-41]. Phylogenetic studies suggest that monocotyls, like L. minor, have low capacity for $\mathrm{Ca}$ accumulation [11]. As it is generally presumed that Sr-ions are homologous to $\mathrm{Ca}$ ions and thus behave like $\mathrm{Ca}$ in organisms, low accumulation capacity of $\mathrm{Sr}$ is possibly linked with low Ca content in plants biomass.

\subsection{Dosimetry}

To obtain accurate dose rate estimates, L. minor was split in two functional units (fronds and roots) each having tissue-specific dose conversion coefficients. The calculated total dose ranged between $0.084 \pm 0.004 \mathrm{mGy} \cdot \mathrm{h}^{-1}$ up to $97 \pm 8 \mathrm{mGy} \cdot \mathrm{h}^{-1}$, of which the lowest dose rate was of the same order of 
magnitude as the IAEA threshold dose rate. After seven days of exposure, the second highest dose rate tested $\left(9.4 \pm 0.5 \mathrm{mGy} \cdot \mathrm{h}^{-1}\right)$ had a negative impact on root growth. According to the EDR values, the root related endpoints were about twenty times more sensitive compared to frond related endpoints. Highly sensitive stress responses on L. minor root growth were also observed in metal and pesticide toxicity. Following this, L. minor root growth/length has been suggested as an alternative bioassay for toxicity testing [42-44]. All endpoints, including frond biomass, frond number and frond area, showed a clear decrease at the highest tested dose rate $\left(97 \pm 8 \mathrm{mGy} \cdot \mathrm{h}^{-1}\right)$. From the available literature dealing with effect studies [45,46], no reports were found on ${ }^{90} \mathrm{Sr}$ or $\beta$-radiation induced effects in aquatic plants, emphasizing a large data gap for aquatic plants $[35,45]$. However, daphnids exposed to a dose rate of $1.8 \mathrm{mGy} \cdot \mathrm{h}^{-1}$ with ${ }^{90} \mathrm{Sr}$ revealed a $36 \%$ reduction in life span, while another study with daphnids using ${ }^{90} \mathrm{Sr}$, showed a decrease of $26 \%$ in fertility rate after exposure to $0.8 \mathrm{mGy} \cdot \mathrm{h}^{-1}$ [45,47]. These dose rates at which growth effects on these aquatic invertebrates were observed are comparable to the dose rates at which $L$. minor root growth was affected. Since $\beta$-particles are proposed to have an RBE factor of 1 (or 3 for low-energy $\beta$-radiation), it is generally accepted that radiological effects caused by $\gamma$-radiation can also be adopted for making radiation comparisons. From a 14 -year field experiment in the Canadian Boreal forest, it has been found that the most sensitive of plant species studied, pine trees, died within 2-3 years when exposed to a dose rate of $5-10 \mathrm{mGy} \cdot \mathrm{h}^{-1}$ and within two weeks at an estimated dose rate of $250-300 \mathrm{mGy} \cdot \mathrm{h}^{-1}$ for pine trees close to the damaged reactor in Chernobyl $[48,49]$. In the present study, EDR 50 values ranged between 250 and $500 \mathrm{mGy} \cdot \mathrm{h}^{-1}$ for L. minor fronds, suggesting that L. minor is more radioresistant than pine trees. Garnier-Laplace, et al. [50] established a species sensitivity distribution curve for terrestrial plants chronically exposed to $\gamma$-radiation under laboratory and field conditions and derived $\mathrm{EDR}_{10}$ values on population related endpoints. Considering the most sensitive EDR 10 endpoint obtained in this study $\left(1.0 \pm 0.5 \mathrm{mGy} \cdot \mathrm{h}^{-1}\right.$ for root dry weight), approximately $50 \%$ of the selected organisms from the SSD curve were more radioresistant in comparison to L. minor.

\subsection{Antioxidative Response}

Oxidative stress related genes are among the most represented genes in responding to radiation in Arabidopsis plants [51,52]. Therefore, to gain more insights in the antioxidative stress response of L. minor plants following $\beta$-radiation exposure, some features of the ROS scavenging biosynthetic pathways involving both enzymatic and non-enzymatic processes were studied. There were minor changes in total ASC content or redox status, although an enhanced activity of APX was found. Increased APX activity with a stable ASC content was also found in other duckweed studies under chemical stress [53]. Under severe oxidative stress conditions, an enhanced APX activity is typically associated with a decrease in reduced ASC content to remove $\mathrm{H}_{2} \mathrm{O}_{2}$ from the cytosol and chloroplasts [54]. Similar, at the highest dose rate tested, the increase in APX activity followed by slight decrease in reduced ASC levels observed points to an increased oxidative stress under these severe radiation conditions.

The concentration of the other antioxidant studied, GSH, significantly increased at the highest tested dose rate of $97 \mathrm{mGy} \cdot \mathrm{h}^{-1}$. An increased GSH content was also found in other plants tissues suffering from oxidative stress to compensate ascorbate oxidation [55-57]. The fact that redox status of GSH remained virtually unchanged could explain the unaltered GR activity since this enzyme is responsible 
for maintaining the GSSG/GSH ratio constant [22]. Also in acutely $\gamma$-irradiated red pepper plants (0-10 Gy), no changes were reported in GR activity upon increasing radiation dose [58]. However, the higher level of GSH and indications that ASA redox starts to decline at $97 \pm 8 \mathrm{mGy} \cdot \mathrm{h}^{-1}$ corroborate the hypothesis that $L$. minor plants have difficulty in controlling the production of ROS under high radiation stress. In addition to APX, also CAT increased at levels below the EDR 10 value. Increased CAT activity is supposed to be an adaptive trait helping to reduce toxic levels of $\mathrm{H}_{2} \mathrm{O}_{2}$ in peroxisomes [54]. Sensitive responses on CAT activity were also reported for $S$. capillata exposed to $65 \mu \mathrm{Gy} \cdot \mathrm{h}^{-1}$ with $\gamma$-radiation. L. minor plants exposed to radiofrequency radiation and in A. thaliana where increased expression levels of CAT1 and CAT3 genes were observed at $50 \mathrm{mGy} \cdot \mathrm{h}^{-1}[25,59,60]$. Therefore, it does seem that plants rely on CAT as their first defense to counter radiation-mediated ROS production. On the contrary, SODs are regarded as the first line of defense against ROS under several abiotic stressors, but according to our findings, $\beta$-radiation did not induce any alterations in SOD enzyme activity $[22,54]$. For acutely $\gamma$-irradiated red pepper, a weak enhancement in SOD activity was found from 2 Gy, while SOD activity in chronically irradiated Stipa capillata $\left(65 \mu \mathrm{Gy} \cdot \mathrm{h}^{-1}\right)$ did not show any response [58,60]. Also, GPOD, GR, and SPOD were not or only slightly affected at the highest dose rate, which might indicate that a $\beta$-irradiation treatment of $97 \pm 8 \mathrm{mGy} \cdot \mathrm{h}^{-1}$ for seven days. However, since growth was clearly hampered at the highest dose rate, available energy supplies might be used for other metabolic pathways to neutralize $\beta$-radiation stress in L. minor plants.

\section{Experimental Section}

\subsection{Culture Stock}

Lemna minor cv. Blarney plants were obtained from Dr. M. Jansen (University College Cork, Cork, Ireland) and cultured aseptically in $250 \mathrm{~mL}$ glass Erlenmeyer flasks containing half-strength Hütner medium [34] under continuous light (Osram 400 W HQI-BT daylight, OSRAM GmbH, Augsburg, Germany, $80-100 \mu \mathrm{mol} \cdot \mathrm{m}^{-2} \cdot \mathrm{s}^{-1}$ ) at $24{ }^{\circ} \mathrm{C}$. Plants were sub-cultured every $10-12$ days by transferring three plants to $100 \mathrm{~mL}$ of fresh growth medium. To obtain sufficient and homogenous plant population, 1 week before the experiment a preculture was initiated with five mature plants per pot (3-4 fronds) in $100 \mathrm{~mL}$ of fresh medium.

\section{2. ${ }^{90}$ Sr Exposure}

For the ${ }^{90} \mathrm{Sr}$ treatment, 3 healthy duckweed plants were chosen randomly and transferred to $250 \mathrm{~mL}$ PC containers (VWR) containing $25 \mathrm{~mL}$ experiment nutrient solution. For the ${ }^{90} \mathrm{Sr}$ uptake experiments, modified K-medium $\left(0.4 \mathrm{mM} \mathrm{Ca}\right.$ and (in $\left.\mathrm{mg} \cdot \mathrm{L}^{-1}\right) 889 \mathrm{KNO}_{3}, 95 \mathrm{Ca}\left(\mathrm{NO}_{3}\right)_{2} \cdot 4 \mathrm{H}_{2} \mathrm{O}, 500 \mathrm{MgSO}_{4} \cdot 7 \mathrm{H}_{2} \mathrm{O}$, $9 \mathrm{Na}$-EDTA, 3 tartaric acid, $1.86 \mathrm{H}_{3} \mathrm{BO}_{3}, 0.22 \mathrm{ZnSO}_{4} \cdot 7 \mathrm{H}_{2} \mathrm{O}, 0.12 \mathrm{Na}_{2} \mathrm{MoO}_{4} \cdot 2 \mathrm{H}_{2} \mathrm{O}, 0.08 \mathrm{CuSO}_{4} \cdot 5 \mathrm{H}_{2} \mathrm{O}$, $3.62 \mathrm{MnCl}_{2} \cdot 4 \mathrm{H}_{2} \mathrm{O}, 5.4 \mathrm{FeCl}_{3} \cdot 6 \mathrm{H}_{2} \mathrm{O}$ with lower $\mathrm{KH}_{2} \mathrm{PO}_{4}$ concentrations $\left(0.5 \mathrm{mg} \cdot \mathrm{L}^{-1}\right)$ [61]) was used containing an activity concentration of $10 \mathrm{kBq} \cdot \mathrm{L}^{-1}{ }^{90} \mathrm{Sr}$, added as $\mathrm{SrCl}_{2}$ (3.7 $\mathrm{MBq}$ stock solution, IDB Belgium) for 6 biological replicates. For the ${ }^{90} \mathrm{Sr}$ effect experiments, a modified Steinberg medium $\left(0.2 \mathrm{mM} \mathrm{Ca}\right.$ and (in $\left.\mathrm{mg} \cdot \mathrm{L}^{-1}\right) 350 \mathrm{KNO}_{3}, 50 \mathrm{Ca}\left(\mathrm{NO}_{3}\right)_{2} \cdot 4 \mathrm{H}_{2} \mathrm{O}, 0.09 \mathrm{KH}_{2} \mathrm{PO}_{4}, 100 \mathrm{MgSO}_{4} \cdot 7 \mathrm{H}_{2} \mathrm{O}$, $1.5 \mathrm{Na}-\mathrm{EDTA}, 0.12 \mathrm{H}_{3} \mathrm{BO}_{3}, 0.18 \mathrm{ZnSO}_{4} \cdot 7 \mathrm{H}_{2} \mathrm{O}, 0.044 \mathrm{Na}_{2} \mathrm{MoO}_{4} \cdot 2 \mathrm{H}_{2} \mathrm{O}, 0.18 \mathrm{MnCl}_{2} \cdot 4 \mathrm{H}_{2} \mathrm{O}, 0.76$ $\mathrm{FeCl}_{3} \cdot 6 \mathrm{H}_{2} \mathrm{O}$ [62]) was used having activity concentrations of $25,250,2500$ and $25,000 \mathrm{kBq} \cdot \mathrm{L}^{-1}{ }^{90} \mathrm{Sr}$ 
for 9 biological replicates. Since L. minor plants exposed in Steinberg medium had the highest $\mathrm{Sr}^{90}$ uptake, and hence highest dose rate, this medium was selected for all effect experiments. The growth of the plants did not differ between both exposure media. The chemical concentration of $\mathrm{Sr}$ at the highest tested activity level amounted to $54 \mathrm{nM}$. Plants were exposed in a growth chamber in sterile environment under continuous light $\left(80\right.$ to $100 \mu \mathrm{mol} / \mathrm{s} \mathrm{m}^{2}$ ) at $24{ }^{\circ} \mathrm{C}$ during ${ }^{90} \mathrm{Sr}$ treatment. Plants were harvested after 7 days of exposure by washing in $1 \mathrm{mM} \mathrm{Pb}\left(\mathrm{NO}_{3}\right)_{2}$ and twice in distilled water for $10 \mathrm{~min}$ in order to discriminate ${ }^{90} \mathrm{Sr}$ accumulation from ${ }^{90} \mathrm{Sr}$ adsorption on root and frond surface. A significant difference was found between plants washed with Pb-solution compared to non-washed or washed with distilled water ( $p<0.05$, data not shown). On the other hand, it was confirmed that there was no significant difference in washing the L. minor plants with a solution containing an excess of $\mathrm{Pb}(1 \mathrm{mM})$ with plants washed in a high Ca-solution $(10 \mathrm{mM}$. data not shown). Fresh weight was determined by weighing all collected plant material from all individual pots after quickly dry patting with clean tissue. For the ${ }^{90} \mathrm{Sr}$ effect experiments, plants from 3 pots were further dried for 2 days at $60{ }^{\circ} \mathrm{C}$ (humidity $<5 \%$ ) for dry weight determination and $\mathrm{Sr}$ uptake measurement. Plants from the remaining 6 pots were, after fresh weight determination, snap frozen in liquid nitrogen for storage at $-80{ }^{\circ} \mathrm{C}$ for biochemical analysis.

\section{3. ${ }^{90} \mathrm{Sr}$ Transfer and Dosimetry}

All collected plant material from 3 individual pots was dry-ashed in a muffle furnace, and subsequently digested in $0.1 \mathrm{M} \mathrm{HCl}$. For ${ }^{90} \mathrm{Sr}$ uptake experiments, all 6 individual pots were used. Digested samples were then diluted 10-fold in $\mathrm{dH}_{2} \mathrm{O}$, vortexed and diluted again 4-fold in scintillation cocktail (Optiphase Hisafe 3, PerkinElmer). Samples $(5 \mathrm{~mL})$ were taken from each pot at the end of the experiment and brought to $20 \mathrm{~mL}$ with the same scintillation cocktail. After careful mixing of sample and scintillation fluid, the ${ }^{90} \mathrm{Sr}$ activity was measured for $60 \mathrm{~min}$ by $\beta$-liquid scintillation counting (Packard 1600TR Tri-Carb, Canberra, Zellik, Belgium). The counting efficiency was determined using a dilution series of ${ }^{90} \mathrm{Sr}$ with known activities. No difference was found between concentrations in samples from growth medium before and after the experimental period indicating that ${ }^{90} \mathrm{Sr}$ was dissolved during the exposure period (data not shown). Concentration Ratios (CR) are expressed as the ratio of ${ }^{90} \mathrm{Sr}$ activity in the plant organ (root and frond) (in $\mathrm{Bq} \cdot \mathrm{kg}^{-1}$ ) and the external solution ${ }^{90} \mathrm{Sr}$ content (expressed in $\left.\mathrm{Bq} \cdot \mathrm{L}^{-1}\right)$. Concentration ratios were calculated on a organ fresh weight $\left(\mathrm{CR}_{\mathrm{FW}}\right)$ and organ dry weight $\left(\mathrm{CR}_{\mathrm{DW}}\right)$ basis. CRs were calculated for roots and fronds.

Dosimetry of radionuclides in species with small sizes requires special attention for accurate dose rate calculations since the range of high-energy $\beta$-radiation in biological matter exceeds the geometrical size of species. Therefore, L. minor plants were split in two functional units for dose calculations. The internal and external dose conversion coefficients (DCC, in $\mu \mathrm{Gy} \cdot \mathrm{h}^{-1} \mathrm{per} \mathrm{Bq} \cdot \mathrm{kg}^{-1} \cdot \mathrm{FW}$ ) were calculated by the ERICA tool for root and shoot separately [39]. The estimated dimensions of fronds and roots necessary for use in ERICA tool were determined by picture analyses using the ImageJ open source software (version 1.43) [63]. An average control L. minor plant had the following dimensions: $0.25 \mathrm{~mm}$ thick, $3 \mathrm{~mm}$ wide and $3.5 \mathrm{~mm}$ deep for frond and the average root length determined at $90 \mathrm{~mm}$ long with a diameter of $0.15 \mathrm{~mm}$. Within the Tier 2 assessment, DCCs can be calculated for any organism by entering the required radionuclide and the organism's dimensions (the 
mass and the three axes that define the ellipsoid used as its simplified representation). The geometries for both organs were separately entered in the software and the DCCs obtained were in agreement with the DCCs obtained from Biermans et al. [19]. The obtained internal DCCs were $9.33 \times 10^{-5}$ and $8.82 \times 10^{-5} \mu \mathrm{Gy} \cdot \mathrm{h}^{-1} / \mathrm{Bq} \cdot \mathrm{kg}^{-1} \cdot \mathrm{FW}$ for frond and root, respectively, and external DCCs were $5.58 \times 10^{-4}$ and $5.63 \times 10^{-4} \mu \mathrm{Gy} \cdot \mathrm{h}^{-1} / \mathrm{Bq} \cdot \mathrm{kg}^{-1} \cdot \mathrm{FW}$.

Since at the start of the experiment, no ${ }^{90} \mathrm{Sr}$ is taken up yet by the plants, a time dependent dose rate approach was designed with the following assumptions: (i) The uptake ratio of ${ }^{90} \mathrm{Sr}$ for both frond and root were given by their $\mathrm{CRFW}_{\mathrm{F}}$, which reached equilibrium phase at harvest time; (ii) The rate of uptake for all tested activity concentrations followed the same equation as obtained by the time course illustrated by Figure 1. Subsequently, the dose rate for fronds and roots $\left(\mu \mathrm{Gy} \cdot \mathrm{h}^{-1}\right)$ is given by Equations (1) and (2), respectively:

$$
\begin{aligned}
& \begin{aligned}
\text { dose rate }_{\text {frond }} & =\frac{1}{t} \int_{0}^{t} D_{\text {total frond }}(t) d t \\
& =A C_{m} \times D C C_{\text {int frond }} \times \int_{0}^{t} \mathrm{CR}_{\mathrm{FW} \text { max frond }}\left(1-e^{-\beta t}\right) d t+\left(A C_{m}\right. \\
& \left.\left.\times D C C_{\text {ext frond }}\right) / 2\right]
\end{aligned} \\
& {\left[\text { dose rate root }=\frac{1}{t} \int_{0}^{t} D_{\text {total root }}(t) d t\right.} \\
& \left.=A C_{m} \times D C C_{\text {int root }} \times \int_{0}^{t} \mathrm{CR}_{\mathrm{FW} \text { max root }}\left(1-e^{-\beta t}\right) d t+A C_{m} \times D C C_{\text {ext root }}\right]
\end{aligned}
$$

where $D_{\text {total }}$ is the total dose $(\mu \mathrm{Gy}), A C_{m}$ is the activity concentration measured in medium $\left(\mathrm{Bq} \cdot \mathrm{L}^{-1}\right)$, $D C C_{\text {int organ }}$ and $D C C_{\text {ext organ }}$ are the internal and external dose conversion coefficients, respectively, for root or frond, unweighted for radiation quality $\left(\mu \mathrm{Gy} \cdot \mathrm{h}^{-1} / \mathrm{Bq} \cdot \mathrm{kg}^{-1} \cdot \mathrm{FW}\right), C R_{\text {max organ }}$ is the organ specific $\mathrm{CR}_{\mathrm{FW}}$ at equilibrium phase $\left(\mathrm{Bq} \cdot \mathrm{kg}^{-1} \cdot \mathrm{FW} / \mathrm{Bq} \cdot \mathrm{L}^{-1}\right) . \beta$ is the slope of the fit from the 7 -day uptake experiment given by Figure 1 and $t$ is the time of the exposure experiment which is set at 7 days. The $D C C_{\text {ext frond }}$ was divided by two since $L$. minor floats on water surface and therefore, only half of the fronds are surrounded by contaminated liquid medium. The total dose rate of the whole plant was calculated as the cumulative dose rate from frond and root separately, including organ-sized correction factors. The correction factors were the average fresh weight ratios for fronds and roots for each dose rate condition; (iii) Since L. minor exhibits an exponential growth with an average reproduction rate of $0.45 \pm 0.02$ fronds per day [64,65], the present experiment exposes approximately three generations of L. minor plants during this seven days treatment, meaning that not all plants were equally exposed with respect to exposure time. However, since the offspring of contaminated organisms are also subjected to equal dose rates, this dynamic approach considers the total population of L. minor as one organism with a treatment time of seven days, as in accordance with the OECD guidelines for the evaluation of chemical toxicants; (iv) ${ }^{90} \mathrm{Sr}$ radionuclides were distributed homogeneously in both organs. However, since the morphologic dimensions of fronds and roots of L. minor fall within the range of the path length of a $\beta$-particle, this effect can be considered as negligible in this dosimetric approach. 


\subsection{Plant Growth}

Growth parameters, in terms of relative frond number, relative frond area and fresh weight were analyzed according to OECD guidelines [33]. Images for determination of average specific growth rate and average specific frond area were taken at Day 0 and 7, and analyzed with ImageJ open source software (version 1.43) [63]. Fresh weight and dry weight for fronds and roots was determined as explained above. The average specific growth rate for the considered endpoint was calculated according to the OECD guidelines 221 [33]. Percentage growth inhibition was subsequently calculated for each test concentration; the average doubling time for frond number in non-irradiated controls was $1.74 \pm 0.02$, achieving the validity criterion of the experiment of $\leq 2.5$ days as stated by the OECD guidelines. The $\mathrm{pH}$ in all test solutions remained constant at $\mathrm{pH} 5.5 \pm 0.5$. There were 9 replicates for each ${ }^{90} \mathrm{Sr}$ treatment condition and control.

\subsection{Antioxidative Enzyme Activities}

Frozen plant tissue $(50-80 \mathrm{mg} \cdot \mathrm{FW})$ was homogenized under frozen conditions with liquid nitrogen using two tungsten carbide beads (Qiagen, Venlo, The Netherlands) of 3-mm diameter in a Retsch Mixer Mill MM400 at $30 \mathrm{~Hz}$ for 3 min after a spatula of insoluble polyvinylpyrrolidone (PVP) was added. Hereafter, $400 \mu \mathrm{L}$ ice-cold $0.1 \mathrm{M}$ Tris-HCl buffer ( $\mathrm{pH}$ 7.8) containing $1 \mathrm{mM}$ EDTA and $1 \mathrm{mM}$ dithiothreitol was added to the frozen homogenized tissue, the mixture was vortexed and subsequently centrifuged at $20,000 \times g$ at $4{ }^{\circ} \mathrm{C}$ for $10 \mathrm{~min}$. The supernatant was kept on ice and used freshly for determination of enzyme capacities. All measurements were performed at room temperature $\left(20-22{ }^{\circ} \mathrm{C}\right.$ ) based on spectrophotometric assays, as previously described [66]. Briefly, The capacity of CAT was analyzed by adding $10 \mu \mathrm{L}$ of supernatants with $190 \mu \mathrm{L}$ of a $49 \mathrm{mM} \mathrm{H}_{2} \mathrm{O}_{2}$ solution. The absorbance at $240 \mathrm{~nm}$ was monitored kinetically. To determine the GPX capacity, $150 \mu \mathrm{L} 0.1 \mathrm{M}$ phosphate buffer, $10 \mu \mathrm{L}$ sample extract and $40 \mu \mathrm{L}$ guajacol mastermix, consisting of $90 \mathrm{mM}$ guaiacol and $163 \mathrm{mM} \mathrm{H} \mathrm{H}_{2} \mathrm{O}_{2}$ mixed on a 1:1 ratio were added in each well of a plastic 96-well plate. Subsequently, the appearance of tetraguajacol was monitored kinetically at $436 \mathrm{~nm}$. SPX capacity was assessed in 96-well UV-plates. In each well, $155 \mu \mathrm{L} 0.1$ TRIS (pH 7.5), $20 \mu \mathrm{L} 98 \mathrm{mM} \mathrm{H} \mathrm{H}_{2} \mathrm{O}_{2}, 20 \mu \mathrm{L}$ plant extract and $5 \mu \mathrm{L}$ syringaldazine (SAZ) were added. The appearance of oxidized SAZ was monitored kinetically at $530 \mathrm{~nm}$. For the determination of the GR capacity, $165 \mu \mathrm{L}$ TRIS-EDTA buffer (0.1 M TRIS; $1 \mathrm{mM} \mathrm{Na}$-EDTA) ( $\mathrm{pH}$ 8), $7 \mu \mathrm{L}$ GR mastermix (1:1 mix of $82 \mathrm{mM}$ GSSG and $6 \mathrm{mM}$ NADPH) and $28 \mu \mathrm{L}$ were added in each well of a 96-well UV-plate. The decrease of NADPH, used for the reduction of GSSG, was followed kinetically at $340 \mathrm{~nm}$. The APX capacity was determined in UV-cuvettes using the Ultrospec 2000 UV/VIS Spectrophotometer (Pharmacia Biotech, Diegem, Belgium). In each cuvette, $665 \mu \mathrm{L}$ HEPES-EDTA (0.1 M HEPES; $1 \mathrm{mM}$ EDTA) buffer, $100 \mu \mathrm{L}$ $30 \mathrm{mM}$ Na-ascorbate, $35 \mu \mathrm{L} 196 \mathrm{mM} \mathrm{H}_{2} \mathrm{O}_{2}$ and $200 \mu \mathrm{L}$ sample extract were added. Subsequently, the appearance of dehydroascorbate (DHA) was measured spectrophotometrically at $298 \mathrm{~nm}$. The activity of SOD was measured on the Ultrospec 2000 UV/VIS Spectrophotometer (Pharmacia Biotech) in plastic cuvettes. In each cuvette, $580 \mu \mathrm{L}$ KH2PO4 buffer (pH 7.8), $100 \mu \mathrm{L} 1 \mathrm{mM}$ EDTA, $100 \mu \mathrm{L}$ $0.5 \mathrm{mM}$ xanthine, $100 \mu \mathrm{L} 0.1 \mathrm{mM}$ cytochrome $\mathrm{C}, 100 \mu \mathrm{L}$ extract and $20 \mu \mathrm{L}$ xanthine oxidase was added. The extent of cytochrome $\mathrm{C}$ reduction (measured at $550 \mathrm{~nm}$ ) was compared to this in a blank, 
not containing any sample extract. Then, the relative inhibition of cytochrome $\mathrm{C}$ reduction by the sample extract was calculated as a measure of SOD capacity. At least 3 biological replicas were analyzed in triplicate (technical replicates). Statistical analysis was performed on the measured data before expressing them relative to controls.

\subsection{Metabolite Measurements}

Oxidized and reduced forms of ascorbate and glutathione were measured spectrophotometrically using a plate-reader assay, as described by [67]. Frozen plant tissue (50-80 $\mathrm{mg} \cdot \mathrm{FW})$ was homogenized under frozen conditions using two tungsten carbide beads (Qiagen) of 3-mm diameter in a Retsch Mixer Mill MM400 at $30 \mathrm{~Hz}$ for $3 \mathrm{~min}$ in $600 \mu \mathrm{L}$ of $200 \mathrm{mM} \mathrm{HCl}$. After centrifugation (15 min, $13,000 \mathrm{rpm}, 4{ }^{\circ} \mathrm{C}$ ), $30 \mu \mathrm{L} 200 \mathrm{mM} \mathrm{NaH}{ }_{2} \mathrm{PO}_{4}(\mathrm{pH} \mathrm{5.6)}$ was added to $300 \mu \mathrm{L}$ of the supernatant. Subsequently, the $\mathrm{pH}$ of all samples was adjusted to $4.5 \mathrm{using} 200 \mathrm{mM} \mathrm{NaOH}$. For the measurement of total AsA, samples were incubated with $25 \mu \mathrm{M}$ DTT and $120 \mathrm{mM} \mathrm{NaH}_{2} \mathrm{PO}_{4}(\mathrm{pH} 7.5)$ for 15 min at $20{ }^{\circ} \mathrm{C}$ to fully reduce the AsA pool. Subsequently, the $\mathrm{pH}$ of the samples was adjusted to $\mathrm{pH} 5.5$, the optimal $\mathrm{pH}$ for ascorbate oxidase, using $200 \mathrm{mM} \mathrm{HCl}$. Further, all measurements were performed as described by Queval and Noctor [54]. Oxidized AsA and reduced GSH were calculated as the difference between total and reduced AsA and total and oxidized GSH, respectively. Furthermore, all measurements were performed as described by Queval and Noctor [67]. At least 3 biological replicas were analzed in triplicate (technical replicates). Statistical analysis was performed on the measured data before expressing them relative to controls.

\subsection{Statistical Analysis}

All data have been presented as mean values \pm standard error (SE). Statistical analysis was performed with the open-source software package R ( R i386 2.15.5; R Foundation for Statistical Computing, Vienna, Austria). Normal distribution was tested with a Shapiro-Wilk test, Barlett's test was used to test for homoscedasticity. To identify any statistical differences between treatments, a one-way ANOVA was performed. When significant differences ( $p$-value $<0.05)$ were found, a Tukey post hoc test was applied to further discriminate between significantly different groups. Student's unpaired two-tailed $t$-test was used for single comparisons. The dose response curves were modeled using the three parameter log-logistic drm equation from the drc package available in the software package $\mathrm{R}(p$-value < 0.05) [68]. Maximal growth reduction was fixed to $100 \%$ and the slope and $\mathrm{EDR}_{50}$ parameters were -0.99 and 238 for frond area, -1.02 and 391 for frond number, -0.96 and 509 for frond fresh weight, -0.92 and 732 for frond fresh weight, -0.67 and 39 for root fresh weight and -0.5 and 51 for root dry weight in the equation model.

\section{Conclusions}

In conclusion, our data demonstrated for the first time that $\beta$-radiation provokes a negative growth in L. minor plants. Submerged roots of L. minor plants were more radiosensitive to $\beta$-radiation compared to the floating fronds. All considered growth related endpoints showed a negative growth at the highest tested dose rate, although only a mild stimulation of the antioxidative defense system was 
observed. L. minor plants relied mainly on catalase to counteract the ROS generation following $\beta$-radiation, although some compounds of the ASC-GSH cycle were also activated, as they possessed higher levels of GSH at the highest tested dose rate level. The regulation of these antioxidative enzymes at the transcriptional level might be crucial in further examinations to support the observed biochemical changes.

\section{Acknowledgments}

The authors thank the Research foundation-Flanders (FWO) (G.A040.11N) and the European Commission Contract Fission-2010-3.5.1-269672 Strategy for Allied Radioecology (www.star-radioecology.org) for financial support of this work. Belgian nuclear research institute $(\mathrm{SCK} \cdot \mathrm{CEN})$ is further thanked for funding the $\mathrm{PhD}$ of $\mathrm{A}$. Van Hoeck.

\section{Author Contributions}

Arne Van Hoeck designed the study, performed the experiments, analyzed the data and wrote the manuscript. May Van Hees and Robin Nauts participated in the experiments. Nele Horemans designed the study and together with Hildegarde Vandenhove critically revised the manuscript. All contributors read and approved the final manuscript.

\section{Conflicts of Interest}

The authors declare no conflict of interest.

\section{References}

1. Bradley, E.S. Radionuclides in biota. In Environmental Contaminants in Biota; CRC Press: Boca Raton, FL, USA, 2011; pp. 703-732.

2. Roussel-Debet, S.; Beaugelin, K. Strontium 90 et Environnement; IRSN: Paris, France, 2005.

3. Buesseler, K.O.; Livingston, H.D. Natural and man-made radionuclides in the black sea. In Adionuclides in the Oceans, Inputs and Inventories; Guéguéniat, P., Germain, P., Métivier, H., Eds.; Institut de Protection et de Surete Nucleaire: Cherbourg, France, 1996; pp. 199-217.

4. Yu, W.; He, J.; Lin, W.; Li, Y.; Men, W.; Wang, F.; Huang, J. Distribution and risk assessment of radionuclides released by fukushima nuclear accident at the northwest pacific. J. Environ. Radioact. 2015, 142C, 54-61.

5. Smith, J.T.; Comans, R.N.; Beresford, N.A.; Wright, S.M.; Howard, B.J.; Camplin, W.C. Chernobyl's legacy in food and water. Nature 2000, 405, 141.

6. Mirzoyeva, N.Y.; Egorov, V.N.; Polikarpov, G.G. Distribution and migration of (9)(0)sr in components of the dnieper river basin and the black sea ecosystems after the chernobyl npp accident. J. Environ. Radioact. 2013, 125, 27-35.

7. Penrose, B.; Beresford, N.A.; Broadley, M.R.; Crout, N.M.J. Inter-varietal variation in caesium and strontium uptake by plants: A meta-analysis. J. Environ. Radioact. 2015, 139, 103-117.

8. Scotti, I.A.; Carini, F. Heavy metal effect on uptake and translocation of $134 \mathrm{cs}$ and $85 \mathrm{sr}$ in aubergine plants. J. Environ. Radioact. 2000, 48, 183-190. 
9. Baeza, A.; Paniagua, J.M.; Rufo, M.; Sterling, A.; Barandica, J. Radiocaesium and radiostrontium uptake by turnips and broad beans via leaf and root absorption. Appl. Radiat. Isot. 1999, 50, 467-474.

10. Kozhevnikova, A.D.; Seregin, I.V.; Bystrova, E.I.; Belyaeva, A.I.; Kataeva, M.N.; Ivanov, V.B. The effects of lead, nickel, and strontium nitrates on cell division and elongation in maize roots. Russ. J. Plant Physiol. 2009, 56, 242-250.

11. Broadley, M.R.; White, P.J. Some elements are more equal than others: Soil-to-plant transfer of radiocaesium and radiostrontium, revisited. Plant Soil 2012, 355, $23-27$.

12. Camps, M.; Rigol, A.; Vidal, M.; Rauret, G. Assessment of the suitability of soil amendments to reduce cs-137 and sr-90 root uptake in meadows. Environ. Sci. Technol. 2003, 37, 2820-2828.

13. Dan, W.; Fangping, W.; Changhe, X.; Yunlai, T.; Xuegang, L. The uptake of cs and sr from soil to radish (raphanus sativus 1.)-potential for phytoextraction and remediation of contaminated soils. J. Environ. Radioact. 2012, 110, 78-83.

14. Willey, N.; Fawcett, K. A phylogenetic effect on strontium concentrations in angiosperms. Environ. Exp. Bot. 2006, 57, 258-269.

15. Chen, M.; Tang, Y.L.; Ao, J.; Wang, D. Effects of strontium on photosynthetic characteristics of oilseed rape seedlings. Russ. J. Plant Physiol. 2012, 59, 772-780.

16. Kanter, U.; Hauser, A.; Michalke, B.; Draxl, S.; Schaffner, A.R. Caesium and strontium accumulation in shoots of arabidopsis thaliana: Genetic and physiological aspects. J. Exp. Bot. 2010, 61, 3995-4009.

17. Moyen, C.; Roblin, G. Uptake and translocation of strontium in hydroponically grown maize plants, and subsequent effects on tissue ion content, growth and chlorophyll a/b ratio: Comparison with ca effects. Environ. Exp. Bot. 2010, 68, 247-257.

18. Copplestone, D.; Brown, J.E.; Beresford, N.A. Considerations for the integration of human and wildlife radiological assessments. J. Radiol. Prot. 2010, 30, 283-297.

19. Biermans, G.; Horemans, N.; Vanhoudt, N.; Vandenhove, H.; Saenen, E.; van Hees, M.; Wannijn, J.; Vives i Batlle, J.; Cuypers, A. An organ-based approach to dose calculation in the assessment of dose-dependent biological effects of ionising radiation in arabidopsis thaliana. J. Environ. Radioact. 2014, 133, 24-30.

20. Hunter, N.; Muirhead, C.R. Review of relative biological effectiveness dependence on linear energy transfer for low-let radiations. J. Radiol. Prot. 2009, 29, 5-21.

21. Hwang, J.E.; Hwang, S.-G.; Kim, S.-H.; Lee, K.J.; Jang, C.S.; Kim, J.-B.; Kim, S.H.; Ha, B.-K.; Ahn, J.-W.; Kang, S.-Y.; et al. Transcriptome profiling in response to different types of ionizing radiation and identification of multiple radio marker genes in rice. Physiol. Plant. 2014, 150, 604-619.

22. Apel, K.; Hirt, H. Reactive oxygen species: Metabolism, oxidative stress, and signal transduction. Annu. Rev. Plant Biol. 2004, 55, 373-399.

23. Gill, S.S.; Tuteja, N. Reactive oxygen species and antioxidant machinery in abiotic stress tolerance in crop plants. Plant Physiol. Biochem. 2010, 48, 909-930.

24. Horemans, N.; Foyer, C.H.; Potters, G.; Asard, H. Ascorbate function and associated transport systems in plants. Plant Physiol. Biochem. 2000, 38, 531-540.

25. Tkalec, M.; Malaric, K.; Pevalek-Kozlina, B. Exposure to radiofrequency radiation induces oxidative stress in duckweed lemna minor 1. Sci. Total Environ. 2007, 388, 78-89. 
26. De Micco, V.; Arena, C.; Pignalosa, D.; Durante, M. Effects of sparsely and densely ionizing radiation on plants. Radiat. Environ. Biophys. 2011, 50, 1-19.

27. White, P.J.; Broadley, M.R. Calcium in plants. Ann. Bot. 2003, 92, 487-511.

28. Guillaume, T.; Chawla, F.; Steinmann, P.; Gobat, J.M.; Froidevaux, P. Disparity in sr-90 and cs-137 uptake in alpine plants: Phylogenetic effect and ca and k availability. Plant Soil 2012, 355, 29-39.

29. Zeller, S.; Feller, U. Long-distance transport of alkali metals in maturing wheat. Biol. Plant. 2000, 43, 523-528.

30. White, P.J. The pathways of calcium movement to the xylem. J. Exp. Bot. 2001, 52, 891-899.

31. Mazen, A.M.A.; Zhang, D.Z.; Franceschi, V.R. Calcium oxalate formation in lemna minor: Physiological and ultrastructural aspects of high capacity calcium sequestration. New Phytol. 2004, 161, 435-448.

32. Franceschi, V.R. Calcium-oxalate formation is a rapid and reversible process in lemna-minor-l. Protoplasma 1989, 148, 130-137.

33. OECD. Lemna sp. Growth Inhibition Test; Guideline 221; Organisation for Economic Co-operation and Development: Paris, France, 2006.

34. Brain, R.A.; Solomon, K.R. A protocol for conducting 7-day daily renewal tests with lemna gibba. Nat. Protoc. 2007, 2, 979-987.

35. UNSCEAR. Effects of Ionizing Radiation United Nations Scientific Committee on the Effects of Atomic Radiation: Unscear 2008 Report to the General Assembly, with Scientific Annexes; United Nations: New York, NY, USA, 2011.

36. Anamika, S.; Eapen, S.; Fulekar, M.H. Phytoremediation technology for remediation of radiostrontium (90sr) and radiocesium $(137 \mathrm{cs})$ by catharanthus roseus (L.) G. Don in aquatic environment. Environ. Eng. Manag. J. 2009, 8, 527-532.

37. Soudek, P.; Valenová, Š.; Vavř́ková, Z.; Vaněk, T. 137cs and 90sr uptake by sunflower cultivated under hydroponic conditions. J. Environ. Radioact. 2006, 88, 236-250.

38. IAEA. Handbook of Parameter Values for the Prediction of Radionuclide Transfer in Terrestrial and Freshwater Environments; Technical Reports Series No. 472; IAEA: Vienna, Austria, 2010.

39. Brown, J.E.; Alfonso, B.; Avila, R.; Beresford, N.A.; Copplestone, D.; Prohl, G.; Ulanovsky, A. The erica tool. J. Environ. Radioact. 2008, 99, 1371-1383.

40. Vadzis, D.R.; Leinerte, M.P.; Seisuma, Z.K.; Sloka, Y.Y. Strontium and Calcium in Natural Freshwater Ecosystemsl; Riga Zinatne: Latvia, 1979.

41. Yankovich, T.L.; Vives i Batlle, J.; Vives-Lynch, S.; Beresford, N.A.; Barnett, C.L.; Beaugelin-Seiller, K.; Brown, J.E.; Cheng, J.J.; Copplestone, D.; Heling, R.; et al. An international model validation exercise on radionuclide transfer and doses to freshwater biota. J. Radiol. Prot. 2010, 30, 299-340.

42. Park, A.; Kim, Y.J.; Choi, E.M.; Brown, M.T.; Han, T. A novel bioassay using root re-growth in lemna. Aquat. Toxicol. 2013, 140-141, 415-424.

43. Gopalapillai, Y.; Vigneault, B.; Hale, B.A. Root length of aquatic plant, lemna minor 1., as an optimal toxicity endpoint for biomonitoring of mining effluents. Integr. Environ. Assess. Manag. 2014, 10, 493-497. 
44. Arts, G.H.P.; Belgers, J.D.M.; Hoekzema, C.H.; Thissen, J. Sensitivity of submersed freshwater macrophytes and endpoints in laboratory toxicity tests. Environ. Pollut. 2008, 153, 199-206.

45. Copplestone, D.; Hingston, J.; Real, A. The development and purpose of the frederica radiation effects database. J. Environ. Radioact. 2008, 99, 1456-1463.

46. Garnier-Laplace, J.; Copplestone, D.; Gilbin, R.; Alonzo, F.; Ciffroy, P.; Gilek, M.; Aguero, A.; Bjork, M.; Oughton, D.H.; Jaworska, A.; et al. Issues and practices in the use of effects data from frederica in the erica integrated approach. J. Environ. Radioact. 2008, 99, 1474-1483.

47. Gudkov, D.I.; Mardarevich, M.G.; Kipnis, L.S.; Ponomaryov, A.V. Long-term combined impact of $90 \mathrm{sr}$ and $\mathrm{pb} 2+$ on freshwater cladoceran. In Protection of the Environment From Ionising Radiation. Proceedings of the Third International Symposium on the Protection of the Environment from Ionising Radiation (SPEIR 3), Darwin, Australia, 22-26 July 2002; Volume 34, pp. 43-49.

48. Amiro, B.D. Response of boreal forest tree canopy cover to chronic gamma-irradiation. J. Environ. Radioact. 1994, 24, 181-197.

49. UNSCEAR. Sources and effects of ionizing radiation. In UNSCEAR 1996 Report to the General Assembly, with Scientific Annex; United Nations Scientific Committee on the Effects of Atomic Radiation: New York, NY, USA, 1996; p. 86.

50. Garnier-Laplace, J.; Geras'kin, S.; Della-Vedova, C.; Beaugelin-Seiller, K.; Hinton, T.G.; Real, A.; Oudalova, A. Are radiosensitivity data derived from natural field conditions consistent with data from controlled exposures? A case study of chernobyl wildlife chronically exposed to low dose rates. J. Environ. Radioact. 2013, 121, 12-21.

51. Kovalchuk, I.; Molinier, J.; Yao, Y.L.; Arkhipov, A.; Kovalchuk, O. Transcriptome analysis reveals fundamental differences in plant response to acute and chronic exposure to ionizing radiation. Mutat. Res. Fundam. Mol. Mech. Mutagen. 2007, 624, 101-113.

52. Gicquel, M.; Taconnat, L.; Renou, J.P.; Esnault, M.A.; Cabello-Hurtado, F. Kinetic transcriptomic approach revealed metabolic pathways and genotoxic-related changes implied in the arabidopsis response to ionising radiations. Plant Sci. 2012, 195, 106-119.

53. Cheng, L.-J.; Cheng, T.-S. Oxidative effects and metabolic changes following exposure of greater duckweed (spirodela polyrhiza) to diethyl phthalate. Aquat. Toxicol. 2012, 109, 166-175.

54. Kim, H.-S.; Kim, Y.-S.; Hahn, K.-W.; Joung, H.; Jeon, J.-H. Chapter 2 reactive oxygen species: Regulation of plant growth and development. In Advances in Botanical Research; Jean-Pierre, J., Ed.; Academic Press: Waltham, MA, USA, 2009; Volume 52, pp. 25-46.

55. Noctor, G.; Gomez, L.; Vanacker, H.; Foyer, C.H. Interactions between biosynthesis, compartmentation and transport in the control of glutathione homeostasis and signalling. J. Exp. Bot. 2002, 53, 1283-1304.

56. Nimptsch, J.; Pflugmacher, S. Ammonia triggers the promotion of oxidative stress in the aquatic macrophyte myriophyllum mattogrossense. Chemosphere 2007, 66, 708-714.

57. Wang, C.; Zhang, S.H.; Wang, P.F.; Hou, J.; Li, W.; Zhang, W.J. Metabolic adaptations to ammonia-induced oxidative stress in leaves of the submerged macrophyte vallisneria natans (lour.) hara. Aquat. Toxicol. 2008, 87, 88-98. 
58. Kim, J.H.; Chung, B.Y.; Kim, J.S.; Wi, S.G. Effects of in planta gamma-irradiation on growth, photosynthesis, and antioxidative capacity of red pepper (capsicum annuum 1.) plants. J. Plant Biol. 2005, 48, 47-56.

59. Vanhoudt, N.; Vandenhove, H.; Horemans, N.; Wannijn, J.; van Hees, M.; Vangronsveld, J.; Cuypers, A. The combined effect of uranium and gamma radiation on biological responses and oxidative stress induced in arabidopsis thaliana. J. Environ. Radioact. 2010, 101, 923-930.

60. Zaka, R.; Vandecasteele, C.M.; Misset, M.T. Effects of low chronic doses of ionizing radiation on antioxidant enzymes and $\mathrm{g}(6) \mathrm{pdh}$ activities in stipa capillata (poaceae). J. Exp. Bot. 2002, 53, 1979-1987.

61. Cedergreen, N.; Abbaspoor, M.; Sorensen, H.; Streibig, J.C. Is mixture toxicity measured on a biomarker indicative of what happens on a population level? A study with lemna minor. Ecotoxicol. Environ. Saf. 2007, 67, 323-332.

62. Steinberg, R. Mineral requirement of lemna minor. Plant Physiol. 1946, 21, 42-48.

63. Abràmoff, M.D.; Magalhaes, P.J.; Ram, S.J. Image Processing Using Imagej. Biophotonics International; Laurin Publishing Co., Inc.: Pittsfield, MA, USA, 2004.

64. Lemon, G.D.; Posluszny, U.; Husband, B.C. Potential and realized rates of vegetative reproduction in spirodela polyrhiza, lemna minor, and wolffia borealis. Aquat. Bot. 2001, 70, 79-87.

65. Ziegler, P.; Adelmann, K.; Zimmer, S.; Schmidt, C.; Appenroth, K.J. Relative in vitro growth rates of duckweeds (lemnaceae) — The most rapidly growing higher plants. Plant Biol. 2015, 17 (Suppl. 1), 33-41.

66. Horemans, N.; van Hees, M.; van Hoeck, A.; Saenen, E.; de Meutter, T.; Nauts, R.; Blust, R.; Vandenhove, H. Uranium and cadmium provoke different oxidative stress responses in lemna minor 1. Plant Biol. 2015, 17 (Suppl. 1), 91-100.

67. Queval, G.; Noctor, G. A plate reader method for the measurement of nad, nadp, glutathione, and ascorbate in tissue extracts: Application to redox profiling during arabidopsis rosette development. Anal. Biochem. 2007, 363, 58-69.

68. Ritz, C.; Streibig, J.C. Bioassay analysis using r. J. Stat. Soft. 2005, 12, 1-22.

(C) 2015 by the authors; licensee MDPI, Basel, Switzerland. This article is an open access article distributed under the terms and conditions of the Creative Commons Attribution license (http://creativecommons.org/licenses/by/4.0/). 